\title{
Cell wall protein and glycoprotein constituents of Aspergillus fumigatus that bind to polystyrene may be responsible for the cell surface hydrophobicity of the mycelium
}

\author{
M. Carmen Peñalver, Manuel Casanova, José P. Martínez \\ and M. Luisa Gil \\ Author for correspondence: José P. Martínez. Tel: +34 63864770. Fax: +3463864770.
e-mail: Jose.Pedro.Martinez@uv.es
}

Departamento de Microbiología y Ecología, Facultad de Farmacia, Universitat de València, Avda. Vicente Andrés Estelles, s/n, 46100-

Burjasot, Valencia, Spain
Cell surface hydrophobicity (CSH) of Aspergillus fumigatus grown both in complex medium (yeast extract/peptone/dextrose; YPD) and minimal (Vogel's N) medium was monitored by assessing attachment of polystyrene microspheres to the cell surface. It was found that mature mycelium was hydrophobic. Treatment of intact mycelium with $\beta$-mercaptoethanol ( $\beta$ ME) abolished binding of the microspheres to hyphal elements, and coating of the microspheres with pME extracts from mycelium inhibited their attachment to intact mycelial cells. A. fumigatus mycelium was tagged in vivo with biotin and treated with $\beta$ ME. The PME extracts were analysed by SDS-PAGE and Western blotting with both peroxidase-conjugated-ExtrAvidin and concanavalin A (ConA). This procedure allowed identification of cell wall surface proteins and glycoproteins. Rabbit polyclonal antisera were raised against $\beta$ ME extracts obtained from cells grown in YPD and Vogel's $\mathbf{N}$ media. These antisera defined some major cell-wall-bound antigens. SDS-PAGE and Western blotting analysis of the cell wall material released by BME and adsorbed on polystyrene microspheres revealed about 19 protein species with apparent molecular masses ranging from 20 to $70 \mathrm{kDa}$, and two highmolecular-mass glycoproteins of 115 and $210 \mathrm{kDa}$. Treatment of cells grown in YPD, but not those grown in Vogel's $N$ medium, with PME released a $55 \mathrm{kDa}$ polypeptide able to adsorb to polystyrene microspheres that was detectable with the antisera. The ability to bind to polystyrene particles exhibited by several protein and glycoprotein species released by $\beta$ ME treatment suggested that these cell wall moieties possess exposed hydrophobic domains that could be responsible for the CSH of mycelium.

Keywords: Aspergillus fumigatus, cell surface hydrophobicity, cell wall, proteins, glycoproteins

\section{INTRODUCTION}

Aspergillus fumigatus is a ubiquitous fungus involved in a variety of allergic and invasive diseases in man such as allergic asthma, allergic bronchopulmonary aspergillosis, aspergilloma and invasive aspergillosis (Bodey \& Vartivarian, 1989; Kwon-Chung \& Bennett, 1991). The most severe form is invasive aspergillosis which has been

Abbreviations: ConA, concanavalin A; $\mathrm{CSH}$, cell surface hydrophobicity; If, immunofluorescence; $\beta \mathrm{ME}, \beta$-mercaptoethanol; $\mathrm{pAb}$, polyclonal antibody. reported as an increasingly important cause of mortality in severely immunocompromised patients, especially those with acute leukaemia and other haematological malignancies, and those undergoing organ transplantation (Cohen, 1991). Although the search for virulence factors has been the focus of many studies in recent years (Bouchara et al., 1995), the mechanisms by which this fungus persists in the lung and causes diseases in certain individuals are still unclear.

Hydrophobic interactions are generally considered to have an important role in the adherence of pathogenic micro-organisms to host cell surfaces (Beachey, 1981). 
Hazen and others have shown that cell surface hydrophobicity (CSH) enhances the ability of Candida albicans to adhere to epithelial tissue, since hydrophobic interactions apparently contribute to maintain and/or increase the number of receptor-ligand contacts between the parasite and the host surfaces (Beachey, 1981; Hazen, 1990; Rotrosen et al., 1986; Silva et al., 1995). In addition, hydrophobic cells are not killed as rapidly as hydrophilic cells by polymorphonuclear neutrophils (Antley \& Hazen, 1988). A similar observation for hydrophobic versus hydrophilic conidia of Aspergillus and Rhizopus species has been made by other workers (for a review, see Diamond, 1988). These results suggest that expression of $\mathrm{CSH}$ could contribute to successful colonization of host tissues and thus to fatal, disseminated candidiasis and aspergillosis.

The nature of the cell wall of $A$. fumigatus has received considerable attention, partly due to recognition of the potential of its molecular constituents as marker antigens for diagnosis (Drouhet et al., 1972; Hearn, 1984, 1992; Hearn \& Sietsma, 1994; Hearn et al., 1990, 1991; Latgé et al., 1994; Reijula et al., 1992; Ste-Marie et al., 1990; Stynen et al., 1992; Wilson \& Hearn, 1982). However, although cell-wall-bound molecules that may account for $\mathrm{CSH}$ have been characterized in other opportunistic fungal pathogens such as C. albicans (Glee et al., 1995; Hazen et al., 1990; López-Ribot et al., 1991), no reports exist on the identification of analogous wall components in $A$. fumigatus.

In this study, we describe for the first time how $A$. fumigatus mycelial filaments grown under different defined, in vitro conditions display strong $\mathrm{CSH}$. Consequently, we have attempted characterization of cell wall components that could be related to $\mathrm{CSH}$ following the procedure previously used to identify similar molecules in C. albicans (López-Ribot et al., 1991). Results presented here indicate that several cell-wall-bound proteins and glycoproteins which are released by treatment of intact cells with $\beta$ mercaptoethanol $(\beta \mathrm{ME})$ may be responsible for $\mathrm{CSH}$ in A. fumigatus cells. This knowledge may help to establish the role that $\mathrm{CSH}$ plays in the virulence and pathogenicity of this fungal species.

\section{METHODS}

Micro-organism and culture conditions. $A$. fumigatus strain 2071, obtained from the Spanish Culture Collection (CECT) was used throughout this work. The organism was grown on plates of Vogel's $\mathrm{N}$ medium (containing $\mathrm{NaNO}_{3}$, glucose, salts and trace elements; Martínez et al., 1991) solidified with Bactoagar $(1.5 \%, \mathrm{w} / \mathrm{v})$ at $25^{\circ} \mathrm{C}$ for $30 \mathrm{~d}$. Mature conidia were harvested from aerial mycelia by washing the plates with sterile $0.05 \%(\mathrm{v} / \mathrm{v})$ Tween 20 in glass-distilled water. Conidia were pelleted from the suspension by centrifugation at $1500 \mathrm{~g}$ for $10 \mathrm{~min}$, washed in sterile water and quantified by haemocytometer counting. Conidia were inoculated at a final concentration of $10^{7} \mathrm{ml}^{-1}$ into liquid YPD $[1 \%(\mathrm{w} / \mathrm{v})$ Bacto-yeast extract, $2 \%(\mathrm{w} / \mathrm{v})$ Bacto-peptone, and $2 \%(\mathrm{w} / \mathrm{v})$ dextrose] or Vogel's $\mathrm{N}$ media. Incubations were carried out at $37{ }^{\circ} \mathrm{C}$ for different times for each experiment (see below). Finally, mycelium was harvested from liquid cultures by filtration
(Millipore HA filters, $0.45 \mu \mathrm{m}$ pore size) and washed thoroughly with double-glass-distilled water. The mycelial pad was used immediately or frozen and kept at $-20^{\circ} \mathrm{C}$ until required.

Assessment of CSH. CSH of individual hyphal cells was determined by light microscopy observations, following attachment to the surface of the cells of polystyrene microspheres $(0.801 \pm 0.036 \mu \mathrm{m}$ diameter $)$ having a low negative charge density essentially as described by Hazen \& Hazen (1987). Briefly, cells from $1.5 \mathrm{ml}$ aliquots of culture medium were harvested and resuspended in $0.15 \mathrm{ml} 0.05 \mathrm{M}$ sodium phosphate buffer, $\mathrm{pH} 7.4$ (buffer A) kept at $0-4{ }^{\circ} \mathrm{C}$ and mixed in acid-washed glass tubes with $150 \mu \mathrm{l}$ of a dilution of the microsphere stock solution made in the same chilled buffer $A$ to achieve an approximate concentration of $9 \times 10^{8}$ microspheres $\mathrm{ml}^{-1}$. The mixtures were rapidly equilibrated to $28^{\circ} \mathrm{C}$ in a water bath and stirred for $30 \mathrm{~s}$ in a vortex mixer. Samples were withdrawn from the mixtures and observed with a phasecontrast Zeiss III photomicroscope. Overall hydrophobicity of the population of resting conidia was determined by an aqueous/hydrocarbon biphasic partition assay based on the procedure of Rosenberg et al. (1980) as modified by Hazen \& Hazen (1987). Cells were suspended in buffer A to yield an $\mathrm{OD}_{600}$ of $0 \cdot 200 \pm 0.020$ (measured in a Shimadzu UV-160 spectrophotometer). Samples of $1.2 \mathrm{ml}$ from these suspensions were mixed with $0.3 \mathrm{ml}$ cyclohexane and vigorously vortexed for $3 \mathrm{~min}$. The phases were then allowed to separate and the percentage change in $\mathrm{OD}_{600}$ of the aqueous phase was considered the hydrophobicity value of the entire conidial population.

Chemical treatments of cells. Cells present in $1 \mathrm{ml}$ aliquots withdrawn from the liquid cultures were sedimented by centrifugation $(3000 \mathrm{~g}, 10 \mathrm{~min})$ and resuspended in $1 \mathrm{ml}$ buffer containing the following agents: $\beta \mathrm{ME}$ at $1 \%(\mathrm{v} / \mathrm{v})$ in buffer $\mathrm{A}$, concanavalin $\mathrm{A}(\mathrm{ConA})$ at $100 \mu \mathrm{g} \mathrm{ml}^{-1}$ in $10 \mathrm{mM}$ Tris $/ \mathrm{HCl}$ $(\mathrm{pH} 7.4)$ containing $0.9 \%(\mathrm{w} / \mathrm{v}) \mathrm{NaCl}$ and $3 \%(\mathrm{w} / \mathrm{v}) \mathrm{BSA}$, or $2 \%(\mathrm{v} / \mathrm{v})$ paraformaldehyde in buffer $\mathrm{A}$. Treatments were accompanied by gentle shaking for $30 \mathrm{~min}$. After treatment, cells were washed by centrifugation three times with buffer $A$, and $\mathrm{CSH}$ assessed by determination of attachment of polystyrene microspheres as described above.

Generation of polyclonal antibodies (pAbs). Mycelium grown in both liquid YPD or Vogel's $\mathrm{N}$ media was harvested, washed with distilled water and resuspended in buffer A containing $1 \%$ $\beta$ ME, $5 \mu \mathrm{g}$ aprotinin $\mathrm{ml}^{-1}, 1 \mathrm{mM}$ EDTA and $1 \mathrm{mM}$ PMSF (the cells were resuspended in a volume of buffer equivalent to $1 / 3$ of the original volume of the culture medium in which they were grown), and incubated for $30 \mathrm{~min}$ at $37^{\circ} \mathrm{C}$ in a rotary incubator. After treatment, the cells were sedimented by centrifugation, and the supernatant fluid was recovered, extensively dialysed against glass-distilled water (four changes) for $48 \mathrm{~h}$ at $4{ }^{\circ} \mathrm{C}$, and concentrated by freeze-drying (' $\beta \mathrm{ME}$ extract'). The lyophilized $\beta$ ME extracts were resuspended in a small volume of buffer $A$. Samples of the different $\beta \mathrm{ME}$ extracts [obtained from cells grown in YPD or Vogel's N media ( $\beta$ MEYPD extract and $\beta$ MEV extract, respectively), containing in all cases approximately $1 \mathrm{mg}$ total protein $\mathrm{ml}^{-1}$ ] were emulsified with an equal volume (1 $\mathrm{ml})$ of complete Freund's adjuvant and injected subcutaneously into adult female New Zealand White rabbits. After 3 weeks, the rabbits were boosted in a similar manner with $1 \mathrm{mg}$ of the corresponding $\beta \mathrm{ME}$ extract in incomplete Freund's adjuvant. Seven days later the rabbits were bled and the immunoglobulin fraction was separated from the crude serum as previously described (Casanova et al., 1992b). Antibody titres were maintained by booster injections of the corresponding immunogen mixed with incomplete Freund's adjuvant every 3 weeks. 
Coating of polystyrene microspheres with $\beta$ ME extract. One millilitre of a commercial stock colloidal suspension $[10 \%$ (w/v) solids] of polystyrene microspheres was mixed with $0.5 \mathrm{mg} \beta \mathrm{ME}$ extract (expressed as total protein content) in $1 \mathrm{ml}$ $100 \mathrm{mM}$ glycine/saline buffer ( $\mathrm{pH} \mathrm{8.4)}$. The mixture was incubated overnight at $4{ }^{\circ} \mathrm{C}$. The microspheres were sedimented by centrifugation, washed with buffer $A$ and used in assays to assess $\mathrm{CSH}$ as described above. Coating of polystyrene particles was assessed by means of an agglutination assay using the $\mathrm{pAb}$ preparations raised towards $\beta \mathrm{ME}$ extracts (see above).

ELISA and immunofluorescence (IF). The reactivity of pAbs was assayed by ELISA and by IF according to the procedures described previously (Casanova et al., 1989). IF observations were made on mycelium grown in liquid YPD or Vogel's $\mathrm{N}$ media with a 1:10 dilution of the corresponding antiserum in PBS buffer $(10 \mathrm{mM}$ sodium phosphate buffer, $\mathrm{pH} 7 \cdot 4$, containing $150 \mathrm{mM}$ sodium chloride) containing $1 \% \mathrm{BSA}$. Control experiments were performed with preimmune rabbit serum diluted in PBS buffer at a similar concentration.

Surface-labelling of mycelial filaments with biotin. Mycelium was collected, washed with $100 \mathrm{mM}$ sodium phosphate buffer, $\mathrm{pH} \mathrm{8}$, and resuspended in a volume of the same buffer equivalent to $1 / 3$ of the volume of culture medium in which the cells were grown, containing $1 \mathrm{mg} 3$-sulfo- $N$-hydroxy-succinimide ester (NSH) of biotin $\mathrm{ml}^{-1}$ (NHS-biotin was previously dissolved in dimethyl sulfoxide). After incubation for $1 \mathrm{~h}$ at $28^{\circ} \mathrm{C}$ in a shaking bath, the cells were recovered and washed with $50 \mathrm{mM}$ phosphate buffer, $\mathrm{pH} 6$ and then with $10 \mathrm{mM}$ phosphate buffer, $\mathrm{pH} 7 \cdot 4$. Biotinylated cells were also subjected to treatment with $\beta \mathrm{ME}$ to release cell-wall-bound protein moieties as described above.

Analysis of material released by $\beta$ ME. To assess the existence in the crude materials released by $\beta \mathrm{ME}$ of molecules exhibiting the ability to bind to the surface of the polystyrene microbeads, $2 \mathrm{mg}$ (expressed as total protein content) of the corresponding lyophilized $\beta \mathrm{ME}$ extracts were resuspended in $0.2 \mathrm{ml}$ buffer $A$ and mixed with $0.4 \mathrm{ml}$ stock colloidal suspension of polystyrene microspheres. The mixtures were incubated at $4{ }^{\circ} \mathrm{C}$ for $12 \mathrm{~h}$ with gentle agitation. The microspheres were extensively washed (10 times) by centrifugation ( $2 \mathrm{~min}$ in a Eppendorf microfuge at $10000 \mathrm{~g}$ ) with buffer $\mathrm{A}$, and the washings were pooled, dialysed, concentrated by freeze-drying and resuspended in $0.2 \mathrm{ml}$ buffer A ('unadsorbed material'). The washed microspheres were immediately resuspended in $0.2 \mathrm{ml}$ electrophoresis sample buffer [35\% (v/v) glycerol, $14 \% \beta \mathrm{ME}, 7 \%$ (w/v) SDS and $0.035 \%(\mathrm{w} / \mathrm{v})$ bromphenol blue in $0.5 \mathrm{M}$ Tris/HCl pH 6.8; Laemmli, 1970) and heated for $5 \mathrm{~min}$ in a boiling-water bath. The microspheres were removed by centrifugation and the supernatant mixed with $0.5 \mathrm{vol}$. buffer $A$. The crude and unadsorbed materials were also treated with electrophoresis sample buffer $(1$ vol. sample buffer per 2 vols corresponding sample) at $100^{\circ} \mathrm{C}$ for $5 \mathrm{~min}$ and subjected in parallel with the polystyrene-adsorbed material to SDS-PAGE, followed by blotting to nitrocellulose paper as described below.

PAGE and Western blot techniques. SDS-PAGE was performed essentially by the procedure of Laemmli (1970), using slab gels $(12.5 \%$, w/v, polyacrylamide; with a ratio of acrylamide to bis-acrylamide of $30: 0 \cdot 2$ ) with 3.5 to $4 \%$ polyacrylamide stacking gels. Electrophoretic transfer (Western blot) to nitrocellulose paper was carried out as reported previously (Casanova et al., 1989). Indirect ConA-mediated peroxidase staining of mannoproteins in nitrocellulose blots was done as described elsewhere (Casanova et al., 1989). Biotinylated proteins transferred to nitrocellulose paper were detected as reported previously (Casanova et al., 1992a). Immunodetection of proteins transferred to nitrocellulose was done as described by Casanova et al. (1989), using the pAbs raised against $\beta \mathrm{ME}$ extract from cells grown in Vogel's $\mathrm{N}$ medium (at a final dilution of $1: 1000$ in $10 \mathrm{mM}$ Tris $/ \mathrm{HCl}, \mathrm{pH} 7 \cdot 4$, containing $0.9 \% \mathrm{NaCl}, 0.05 \%$ Tween 20 and $1 \% \mathrm{BSA}$; TBSTB) or from cells grown in YPD medium (at a final dilution of 1:500 in TBSTB). Peroxidase-labelled goat anti-rabbit immunoglobulin diluted 1:3000 in TBSTB was used as the indicator antibody. Protein was visualized by the silver staining procedure of Morrissey (1981).

Miscellaneous. The total protein content of the different samples was determined by the Lowry method with BSA as standard. The total sugar content was determined by the method of Dubois et al. (1956). Gel electrophoresis and blotting reagents, peroxidase- and fluorescein-isothiocyanate-conjugated goat anti-rabbit immunoglobulin $G$ and molecular mass markers were from Bio-Rad. Polystyrene microspheres were obtained from Sigma. Culture medium components, and complete and incomplete Freund's adjuvants were purchased from Difco. All other chemicals were purchased from Sigma.

\section{RESULTS}

\section{Assessment of CSH during growth of conidia to mature mycelia}

Resting conidia were found to be highly hydrophobic as determined by an aqueous/hydrocarbon biphasic partition assay (see Methods), that allows determination of overall CSH for a cell population (Hazen \& Hazen, 1987; López-Ribot et al., 1991). According to the percentage change in $\mathrm{OD}_{600}$ of the aqueous phase, which is proportional to the number of hydrophobic cells that entered the hydrocarbon phase, more than $85 \%$ of resting conidia displayed strong $\mathrm{CSH}$, but after $30 \mathrm{~min}$ of incubation in YPD medium the hydrophobic status of cells began to change (only $60 \%$ of the conidia entered the hydrocarbon phase), and by $3 \mathrm{~h}$ of incubation essentially all the conidia, which had still not germinated, appeared to be hydrophilic and remained in the aqueous phase. These results were in agreement with observations made when $\mathrm{CSH}$ of individual $A$. fumigatus cells grown in liquid YPD medium was determined by an assay based on the attachment of polystyrene microspheres to the cell surface (Hazen \& Hazen, 1987). In this case, swollen, non-germinated conidia and swollen conidia bearing short-length germ tubes exhibited some microspheres non-uniformly attached to their surfaces (Fig. 1a, b; indicated by arrows). However, long mycelial filaments (which appeared after $15 \mathrm{~h}$ or more of incubation) were highly hydrophobic since they showed numerous microspheres attached along the whole length of the hyphae (Fig. 1c). No differences in $\mathrm{CSH}$, as determined by the attachment of microspheres to the cell surface, were found between mycelial filaments grown in YPD or Vogel's N media (Fig. 1 and results not shown, respectively).

\section{Effects of different treatments on CSH}

Treatment of mycelium grown in YPD or Vogel's $\mathrm{N}$ media with $\beta \mathrm{ME}$ abolished attachment of the polystyrene microspheres to the cell surface (Fig. 1d and results not shown, respectively). Coating of polystyrene particles with $\beta \mathrm{ME}$ extract prior to the $\mathrm{CSH}$ assessment assay 

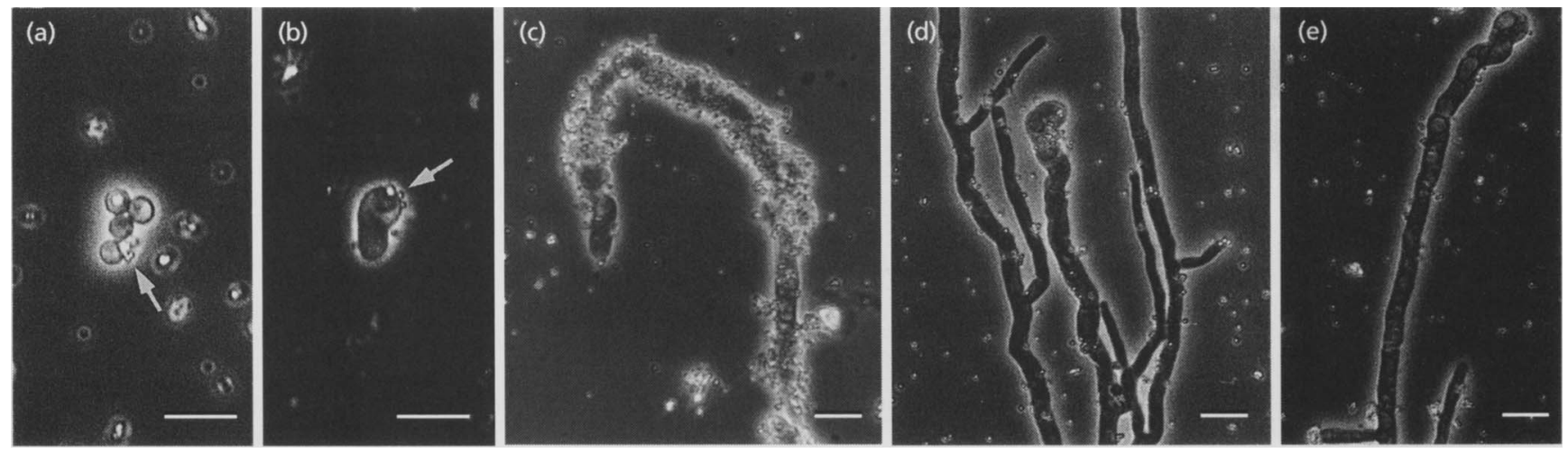

Fig. 1. Appearance of different cell morphologies of $\boldsymbol{A}$. fumigatus grown in YPD medium after mixing with polystyrene microspheres to assess CSH as described in Methods. (a) Swollen conidia prepared by incubating the resting conidia for about $5 \mathrm{~h}$ at $37^{\circ} \mathrm{C}$; (b) germinated swollen conidia bearing short-length hyphae obtained by incubating the swollen conidia for an additional period of $5 \mathrm{~h}$ at $37^{\circ} \mathrm{C}$; (c) mature hyphae obtained after $10 \mathrm{~h}$ incubation of swollen conidia at $37^{\circ} \mathrm{C}$; (d) $\beta$ ME-treated mycelial filaments; (e) intact mature mycelial filaments previously coated with $\beta \mathrm{ME}$ extract. Bars, $10 \mu \mathrm{m}$.

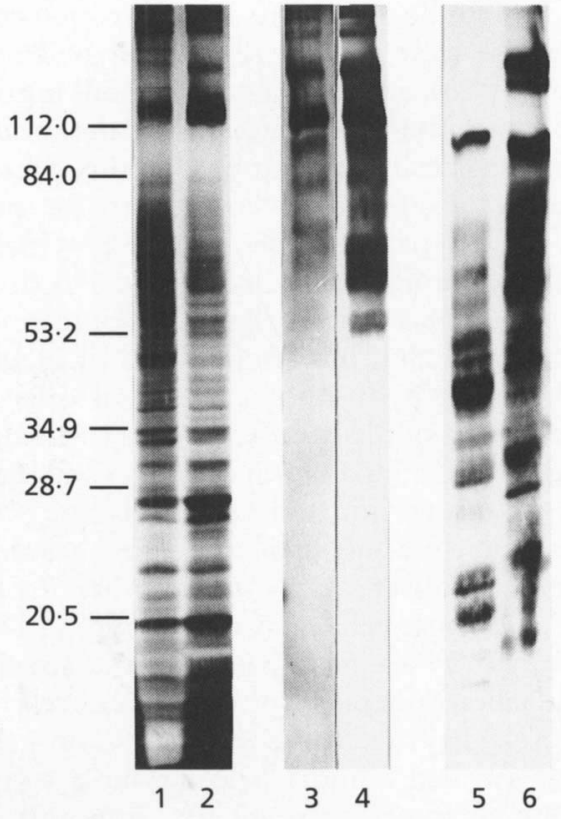

Fig. 2. Characterization of proteinaceous components released by $\beta \mathrm{ME}$ from the cell surface of mycelium grown in Vogel's $\mathrm{N}$ medium (lanes 1, 3 and 5) or YPD medium (lanes 2, 4 and 6). Components were separated by SDS-PAGE and revealed by silver nitrate staining (lanes 1 and $2 ; 75 \mu \mathrm{g}$ total protein per well) or by indirect ConA-mediated peroxidase staining following blotting onto nitrocellulose paper (lanes 3 and $4 ;$ $150 \mu \mathrm{g}$ total sugars per well). Biotinylated polypeptides released from the cell surface by $\beta$ ME treatment were also separated by SDS-PAGE, transferred to nitrocellulose, and detected with ExtrAvidin-peroxidase conjugate (lanes 5 and 6; $75 \mu \mathrm{g}$ total protein per well). Molecular masses (in $\mathrm{kDa}$ ) of standard proteins run in parallel are shown on the left.

inhibited their binding to the surface of intact mycelial cells (Fig. 1e). Fixation of cells with $2 \%$ paraformaldehyde did not cause any detectable effect on $\mathrm{CSH}$ as determined by their ability to bind the microspheres, whereas Con $\mathrm{A}$ treatment or pre-incubation of mycelium with pAbs raised towards $\beta \mathrm{ME}$ extracts significantly reduced (yet did not abolish) attachment of polystyrene particles to the cell surface (data not shown).

\section{Characterization of protein species released by $\beta \mathrm{ME}$ from the walls of mycelial cells grown in complex or minimal media}

The material released by $\beta \mathrm{ME}$ from intact $A$. fumigatus cells grown in YPD or Vogel's $N$ media was first analysed by SDS-PAGE and stained with silver nitrate (Fig. 2, lanes 1 and 2). Treatment with $\beta \mathrm{ME}$ solubilized a complex array of high-to low-molecular-mass species (about 30-35 different polypeptides), randomly distributed throughout the entire molecular mass range (from 10 to $>112 \mathrm{kDa}$ ). The polypeptide profiles obtained from the $\beta \mathrm{MEV}$ and $\beta$ MEYPD extracts (Fig. 2, lanes 1 and 2 , respectively) were quite similar, although quantitative differences in the amount of protein in several bands were detected. These patterns were extremely reproducible from one experiment to another.

ConA, a lectin with a high affinity for $(1 \rightarrow 2)-\alpha-D-$ mannooligosaccharides and glucose (Goldstein \& Hayes, 1978 ), was selected as a probe to detect wall glycoproteins released by $\beta \mathrm{ME}$. Western blot analysis of the $\beta \mathrm{ME}$ extracts with ConA is shown in lanes 3 and 4 of Fig. 2. Again, $\beta \mathrm{MEV}$ and $\beta \mathrm{MEYPD}$ extracts (lanes 3 and 4 , respectively) gave similar profiles of glycoprotein species, within an apparent molecular mass range of 50 to $>112 \mathrm{kDa}$, thus suggesting that the low-molecular-mass polypeptides $(<50 \mathrm{kDa})$ detected in the polyacrylamide gels by means of silver staining (Fig. 2, lanes 1 and 2) contain no glucose and/or mannose polymers.

In vivo labelling of cells with biotin, a technique that has been previously employed by our group to identify surface cell wall protein and glycoprotein components in $C$. 

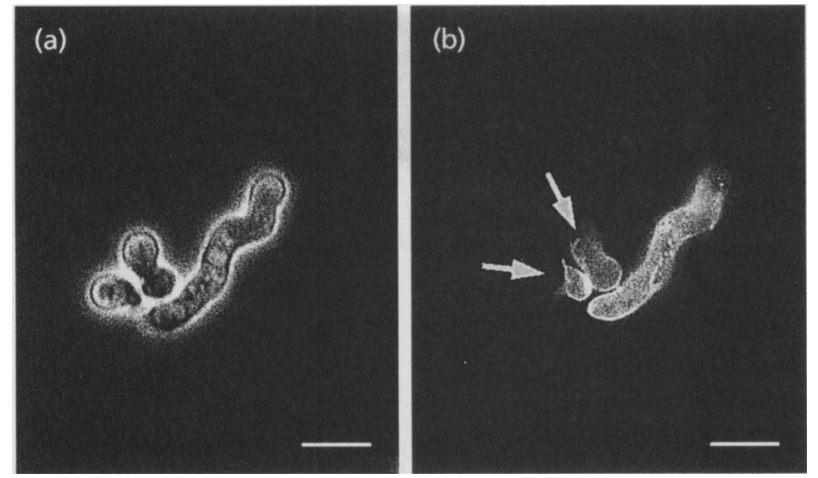

Fig. 3. Phase-contrast (a) and IF (b) photographs of filamentous growth of $\boldsymbol{A}$. fumigatus stained with antibodies raised against the components released by $\beta \mathrm{ME}$ from the cell surface of mycelia grown in YPD medium. The cells shown were also grown in YPD medium. Arrows point to the location of conidia, which exhibited no fluorescence under UV illumination. Bar, $10 \mu \mathrm{m}$.

albicans (Casanova et al., 1992a), was used in this work to delineate further the wall moieties released by $\beta \mathrm{ME}$ from $A$. fumigatus mycelial cells. Biotinylated proteins were extracted from the cell wall of intact mycelia by treatment with $\beta \mathrm{ME}$, separated by SDS-PAGE, transferred to nitrocellulose sheets and detected with ExtrAvidin- peroxidase conjugate as described in Methods (Fig. 2, lanes 5 and 6). Although silver staining of polyacrylamide gels revealed a similar polypeptide pattern in both extracts $(\beta \mathrm{MEV}$ and $\beta \mathrm{MEYPD}$ ) as mentioned above (Fig. 2, lanes 1 and 2), biotinylation allowed identification of several polypeptides whose expression seemed to be dependent on the type of culture media where the cells were grown (compare lane 5 versus lane 6 in Fig. 2). In addition, the number of biotinylated moieties was found to be lower in the $\beta \mathrm{MEV}$ extract (Fig. 2, lane 5; 11 bands) than in the $\beta$ MEYPD extract (Fig. 2, lane 6; 18 bands).

\section{Generation of pAbs against $\beta$ ME extracts}

pAbs against wall components present in $\beta \mathrm{MEV}$ (pAb anti- $\beta \mathrm{MEV}$ ) and $\beta$ MEYPD (pAb anti- $\beta$ MEYPD) extracts were tested by ELISA and IF. By ELISA, each antibody cross-reacted with the two extracts, with essentially the same intensity (positive reactions were obtained at $1: 1000-1: 5000$ dilutions). The IF assay showed that both pAbs specifically labelled the surface of the hyphal extensions of the organism regardless of the culture medium in which the cells were grown, which confirmed the cross-reactivity detected by ELISA. Fig. 3(b) shows a representative IF field of cells grown in YPD medium and probed with $\mathrm{pAb}$ anti- $\beta$ MEYPD. Conidia were not stained following reaction with the $\mathrm{pAb}$ preparations (Fig. 3b, arrows). (a)

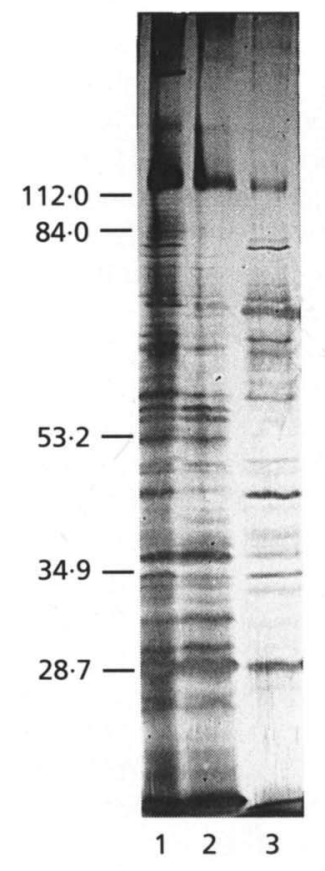

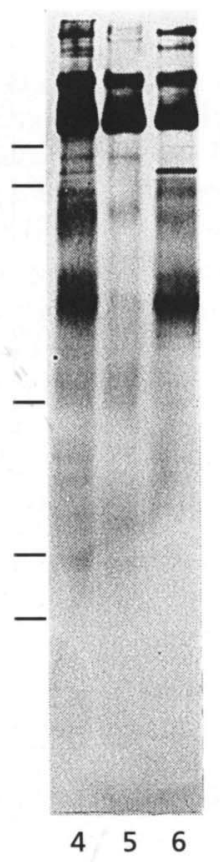
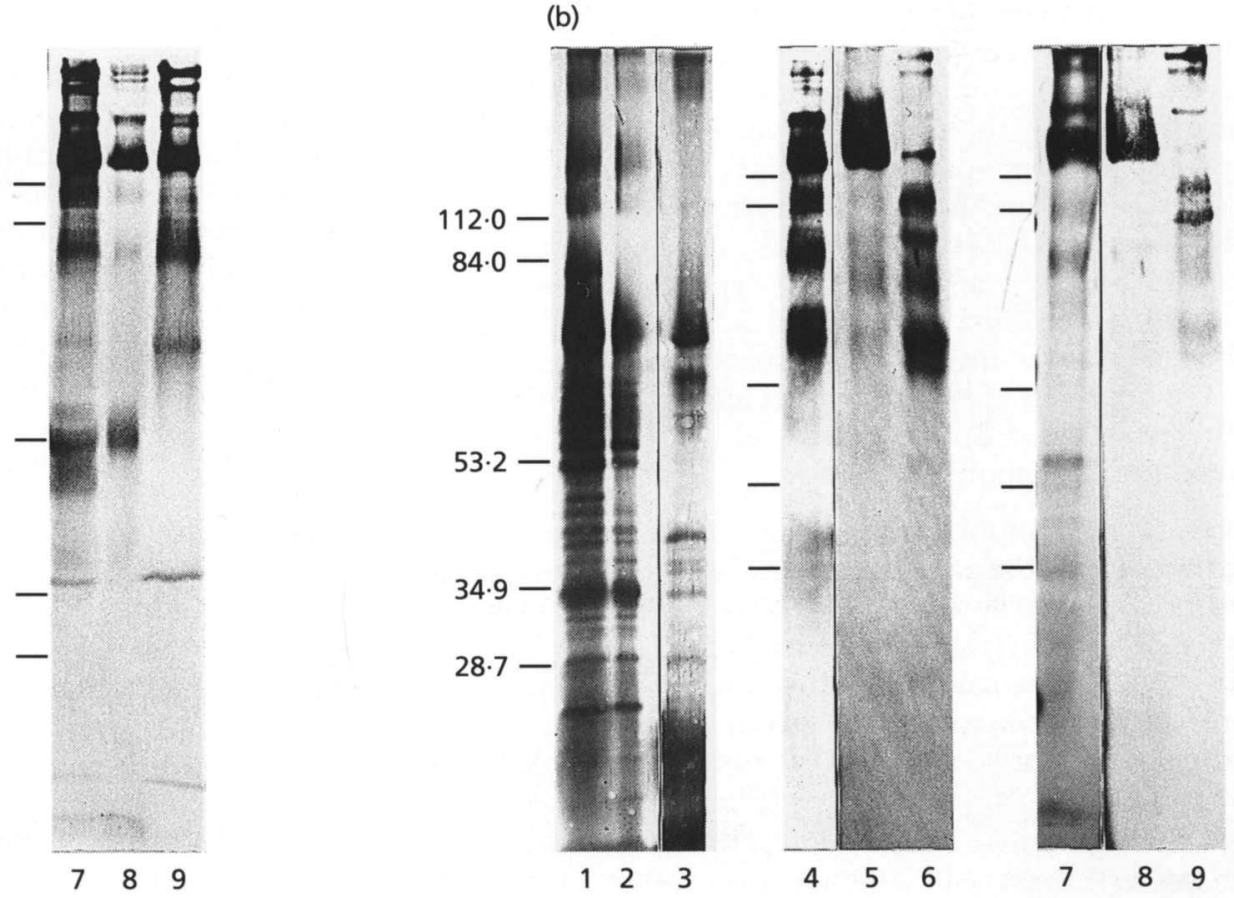

Fig. 4. Characterization of proteinaceous components released by $\beta \mathrm{ME}$ from the cell surface of mycelia grown in YPD medium (a) or Vogel's $N$ medium (b) that bind to polystyrene microspheres. Crude material (lanes 1, 4 and 7), polystyrene-adsorbed material (lanes 2, 5 and 8) and unadsorbed material (lanes 3, 6 and 9) were analysed by SDS-PAGE and revealed by silver nitrate staining (lanes $1-3 ; 75 \mu \mathrm{g}$ total protein per well) or blotted onto nitrocellulose paper and revealed by indirect ConA-mediated peroxidase staining (lanes $4-6 ; 150 \mu \mathrm{g}$ total sugars per well) and immunodetection with pAb anti- $\beta$ MEYPD (a, lanes $7-9 ; 150 \mu \mathrm{g}$ total protein per well) or with pAb anti- $\beta$ MEV (b, lanes $7-9 ; 150 \mu \mathrm{g}$ total protein per well). Molecular masses (in $\mathrm{kDa}$ ) of standard proteins are shown on the left. 


\section{Characterization of wall proteins adsorbed on polystyrene microspheres}

Ability of $\beta \mathrm{ME}$-solubilized mycelial surface proteins and glycoproteins to be specifically adsorbed on polystyrene microspheres was assayed, since affinity for this plastic material may be considered as indirect evidence of the hydrophobic nature of polypeptide moieties (López-Ribot et al., 1991, 1995).

The polystyrene-adsorbed protein profile from $\beta M E Y P D$ extract revealed by silver staining of the gels (Fig. 4a, lane 2) appeared to be quite similar to that from $\beta \mathrm{MEV}$ extract (Fig. 4b, lane 2). About 21 polypeptide species exhibiting affinity for the surface of polystyrene microspheres were detected, with molecular masses ranging from 20 to > $112 \mathrm{kDa}$.

Analysis with ConA-peroxidase staining revealed, as previously stated (see Fig. 2, lanes 3 and 4), a complex array of medium- to high-molecular-mass glycoprotein species (from 50 to $>112 \mathrm{kDa}$ ) in crude $\beta$ MEYPD (Fig. $4 \mathrm{a}$, lane 4) and $\beta \mathrm{MEV}$ (Fig. 4b, lane 4). Adsorption of the crude material on polystyrene microspheres showed the affinity for polystyrene of two proteins with apparent molecular masses of 115 and $210 \mathrm{kDa}$ (Fig. 4a, b, lanes 5). The polystyrene-adsorbed glycoprotein profile of $\beta$ MEYPD extracts appeared to be substantially identical of that from $\beta \mathrm{MEV}$ extracts (compare Fig. 4a, lane 5 versus Fig. 4b, lane 5). However, the two high-molecularmass (115 and $210 \mathrm{kDa}$ ) polystyrene-adsorbed glycoproteins from $\beta$ MEYPD extract were still present in the unadsorbed material, whereas in the case of $\beta \mathrm{MEV}$ extract these species were almost completely adsorbed to polystyrene particles (compare lanes 6 and 9 in Fig. 4a versus $4 \mathrm{~b})$. Increasing the concentration of polystyrene microspheres in the adsorption assay did not cause any detectable reduction in the intensity of these two bands in the unadsorbed $\beta$ MEYPD extract (data not shown). Most of the polystyrene-adsorbed polypeptides detected by silver staining (Fig. 4a, b, lanes 2), particularly those in the medium- to low-molecular-mass range (from $70 \mathrm{kDa}$ down to about $20 \mathrm{kDa}$ ), lack reactivity towards ConA (Fig. 4a, b, lanes 2) and, most likely, are minor cell-wallbound protein moieties.

Western immunoblot analysis of $\beta \mathrm{MEYPD}$ and $\beta \mathrm{MEV}$ extracts using the $\mathrm{pAbs}$ raised against the corresponding materials (pAbs anti- $\beta \mathrm{MEYPD}$ and anti- $\beta \mathrm{MEV}$, respectively) as probes, is shown in lane 7 of Fig. $4 \mathrm{a}$ and $4 \mathrm{~b}$. The pAbs also recognized a complex array of medium- to high-molecular-mass-species (from 40 to $>112 \mathrm{kDa}$ ), most of them glycoproteins, as can be concluded from their reactivity against ConA (Fig. 4a, b, lanes 4). In addition, both $\mathrm{pAb}$ preparations also recognized several bands that were not stained with ConA-peroxidase. Immunodetection of material released from cells grown in YPD medium and adsorbed on the polystyrene microspheres (Fig. 4a, lane 8) revealed one other major protein with an apparent molecular mass of $55 \mathrm{kDa}$. This band (Fig. 4a, lane 8) did not exhibit reactivity toward ConA (Fig. 4a, lane 5). The pAbs also recognized the 115 and $210 \mathrm{kDa}$ glycoprotein species mentioned above that exhibited affinity for the surface of the polystyrene microspheres (Fig. 4a, b, lanes 8).

\section{DISCUSSION}

The outermost cell wall layer of Aspergillus conidia is characterized by the presence of interwoven fascicles of clustered proteinaceous microfibrils called rodlets, the formation of which is encoded by the recently cloned gene $\operatorname{rod} A$ (Thau et al., 1994). This layer is insoluble and is responsible for the conidial hydrophobicity of Aspergillus spp. (Parta et al., 1994). Inhaled resting conidia lose their hydrophobic outer surface layers, initially swell and then germinate to form mycelial filaments that may invade host tissues (Diamond, 1988). In this work, we determined $\mathrm{CSH}$ of $A$. fumigatus by different methods and showed that the strong $\mathrm{CSH}$ exhibited by resting conidia disappeared after $3 \mathrm{~h}$ of incubation in YPD medium, and that swollen conidia and short germ tubes appeared to be essentially non-hydrophobic, yet mature mycelial filaments were highly hydrophobic. Similar results have been reported in $C$. albicans, where mycelial filaments were invariably highly hydrophobic regardless of the CSH displayed by the mother blastoconidia (López-Ribot $e t$ al., 1991). The fact that treatment of cells with $\beta \mathrm{ME}$ or coating of the polystyrene particles with $\beta \mathrm{ME}$ extracts abolished attachment of the microspheres to the mycelial surface suggests that the $\mathrm{CSH}$ of $A$. fumigatus mycelium can be ascribed to cell surface components susceptible to release by treatment with reducing agents such as $\beta \mathrm{ME}$.

Extracts obtained by treatment of $A$. fumigatus cells with $\beta \mathrm{ME}$, which releases fungal cell wall components without substantially altering their native characteristics (Calderone \& Braun, 1991), were analysed by SDSPAGE and Western blotting. As reported for C. albicans (Casanova \&. Chaffin, 1991; Casanova et al., 1992a; Chaffin \& Stocco, 1983; López-Ribot et al., 1991; Ponton \& Jones, 1986), $\beta \mathrm{ME}$ also solubilized from the walls of $A$. fumigatus hyphae a complex array of protein and glycoprotein species distributed within a wide molecular mass range (from 10 to $>112 \mathrm{kDa}$ ). Silver staining of polyacrylamide gels revealed similar polypeptide patterns in $\beta \mathrm{ME}$ extracts obtaired from cells grown in complex (YPD) or minimal (Vogel's $\mathrm{N}$ ) media. However, in vivo labelling of mycelial filaments with biotin demonstrated qualitative and quantitative differences between wall proteins released by $\beta \mathrm{ME}$ from cells grown in the two media. This suggests that growth in different culture media may affect the topological localization of particular protein components within the cell wall structure (and in turn accessibility of biotin to target molecules), rather than modifying the qualitative pattern of proteins released by $\beta \mathrm{ME}$ from the cell wall of $A$. fumigatus mycelium. Some qualitative differences between silver-stained and biotin-labelled polypeptide patterns (compare lanes 5 and 6 versus lanes 1 and 2 in Fig. 2), may reflect the existence of (i) minor cell wall components with a fast metabolic turnover, (ii) proteins with low affinity for biotin, or (iii) proteins located deep within the wall structure or masked by other wall components (both possibilities would hamper accessibility of biotin to target molecules). 
IF assays revealed that antigens recognized by the different $\mathrm{pAb}$ preparations were only detectable at the surface of mycelial filaments and, interestingly, either long mature hyphae or short young mycelial filaments exhibited basically the same homogeneous confluent fluorescent pattern, yet only mature hyphal elements displayed strong $\mathrm{CSH}$. This observation suggests that cell-wall-bound components responsible for $\mathrm{CSH}$ are expressed late during the germination process or, alternatively, they could be masked by hydrophilic molecules in short germ tubes.

In order to establish the particular cell wall moieties to which the hydrophobic character exhibited by the surface of $A$. fumigatus hyphae could be ascribed, we analysed the capacity of the protein and glycoprotein species released by $\beta \mathrm{ME}$ to be adsorbed onto the surface of polystyrene microspheres, which might be an indication of the possible hydrophobic character of such molecules (LópezRibot et al., 1991, 1995). Patterns of $\beta$ ME-released, polystyrene-adsorbed (hydrophobic?) proteins írom cells grown in complex (YPD) or minimal (Vogel's N) media were similar, which is in agreement with the fact that mycelial filaments consistently exhibited strong $\mathrm{CSH}$ regardless of the culture medium in which the cells were grown, although some qualitative and/or quantitative differences were noted depending on the medium used. Thus, $\beta$ MEYPD extracts may contain specific highmolecular-mass hydrophilic glycoproteins (as revealed by both ConA-mediated staining and immunodetection with pAbs) that can be masked by other hydrophobic species with similar electrophoretic mobility (between 115 and $210 \mathrm{kDa}$ ) present in both $\beta$ MEYPD and $\beta \mathrm{MEV}$ extracts. This may account for the presence of non-adsorbed highmolecular-mass proteins only in the residual material after adsorption of $\beta$ MEYPD extracts onto polystyrene. In addition, the walls of cells grown in YPD could contain more hydrophobic cell surface species (for instance, a $55 \mathrm{kDa}$ polystyrene-adsorbed polypeptide) than the cells grown in Vogel's $\mathrm{N}$ medium.

In summary, we report here for the first time that $A$. fumigatus mycelia displayed strong $\mathrm{CSH}$, a property that may have a potential role as a virulence determinant in medically important fungi (Hazen, 1990), and that $\mathrm{CSH}$ may be conferred by cell-wall-bound proteins and/or glycoproteins that are released by treatment of intact cells with $\beta$ ME. This knowledge may help to establish the role (if any) that CSH plays in the virulence and pathogenicity of this fungal species. In addition, hydrophobic interactions may be of great importance in promoting further invasion of tissues by the filamentous forms of the fungus, once the initial colonization of host cells and/or mucosal surfaces by conidia, the infectious air-borne propagules, has occurred. It has to be stressed that $A$. fumigatus conidia are able to adhere to fibrinogen, laminin, complement and fibronectin via proteins (receptors?) of the outer cell wall (Annaix et al., 1992; Coulot et al., 1994; Peñalver et al., 1996; Sturtevant \& Latgé, 1992; Tronchin et al., 1993) but binding sites are not present on the surface of mycelial elements. In this context, $\mathrm{CSH}$ could represent an indirect mechanism allowing attachment of $A$. fumigatus to host tissues leading to further development of infection.

\section{ACKNOWLEDGEMENTS}

The support of grants from the DGICyT (PM92-0246) and CICyT (SAF95-0595), Ministerio de Educación y Ciencia, Spain, is acknowledged.

\section{REFERENCES}

Annaix, V., Bouchara, J. P., Larcher, G., Chabasse, D. \& Tronchin, G. (1992). Specific binding of fibrinogen fragment $\mathrm{D}$ to Aspergillus fumigatus conidia. Infect Immun 60, 1747-1755.

Antley, P. P. \& Hazen, K. C. (1988). Role of yeast cell growth temperature on Candida albicans virulence in mice. Infect Immun 56, 2884-2890.

Beachey, E. H. (1981). Bacterial adherence: adhesin-receptor interactions mediating the attachment of bacteria to mucosal surfaces. $J$ Infect Dis 143, 325-345.

Bodey, G. P. \& Vartivarian, S. (1989). Aspergillosis. Eur J Clin Microbiol Infect Dis 8, 413-437.

Bouchara, J. P., Tronchin, G., Larcher, G. \& Chabasse, D. (1995). The search for virulence determinants in Aspergillus fumigatus. Trends Microbiol 3, 327-330.

Calderone, R. A. \& Braun, P. C. (1991). Adherence and receptor relationships in Candida albicans. Microbiol Rev 55, 1-20.

Casanova, M. \& Chaffin, W. L. (1991). Cell wall glycoproteins of Candida albicans as released by different methods. J Gen Microbiol 137, 1045-1051.

Casanova, M., Gil, M. L., Cardeñoso, L., Martínez, J. P. \& Sentandreu, R. (1989). Identification of wall-specific antigens synthesized during germ tube formation by Candida albicans. Infect Immun 57, 262-271.

Casanova, M., López-Ribot, J. L., Martínez, J. P. \& Sentandreu, R. (1992a). Characterization of cell wall proteins from yeast and mycelial cells of Candida albicans by labelling with biotin: comparison with other techniques. Infect Immun 60, 4898-4906.

Casanova, M., Lopez-Ribot, J. L., Monteagudo, C., LLombartBosch, A., Sentandreu, R. \& Martínez, J. P. (1992b). Identification of a 58-kilodalton cell surface fibrinogen-binding mannoprotein from Candida albicans. Infect Immun 60, 4221-4229.

Chaffin, W. L. \& Stocco, D. M. (1983). Cell wall proteins of Candida albicans. Can J Microbiol 29, 1438-1444.

Cohen, J. (1991). Clinical manifestations and management of aspergillosis in the compromised patient. In Fungal Infection in the Compromised Patient, 2nd edn, pp. 117-152. Edited by D. W. Warnock \& M. D. Richardson. Chichester: John Wiley.

Coulot, P., Bouchara, J. P., Renier, G., Annaix, V., Planchenault, C., Tronchin, G. \& Chabasse, D. (1994). Specific interaction of Aspergillus fumigatus with fibrinogen and its role in cell adhesion. Infect Immun 62, 2169-2177.

Diamond, R. D. (1988). Fungal surfaces: effects of interactions with phagocytic cells. Rev Infect Dis 10, S428-S431.

Drouhet, E., Camay, L. \& Segretain, G. (1972). Valeur de l'immunoprecipitation et de l'immunofluorescence indirecte dans les aspergilloses broncho-pulmonaires. Ann Inst Pasteur 123, 379-395.

Dubois, M., Gilles, K. A., Hamilton, J. K., Rebers, P. A. \& Smith, F. (1956). Colorimetric method for determination of sugars and related substances. Anal Chem 28, 350-356.

Glee, P. M., Sundstrom, P. \& Hazen, K. C. (1995). Expression of 
surface hydrophobic proteins by Candida albicans in vivo. Infect Immun 63, 1373-1379.

Goldstein, I. J. \& Hayes, C. E. (1978). The lectins: carbohydratebinding proteins of plants and animals. In Advances in Carbobydrate Chemistry and Biochemistry, vol. 35, pp. 127-340. Edited by R. S. Tipson \& D. Horton. New York: Academic Press.

Hazen, K. C. (1990). Cell surface hydrophobicity of medically important fungi, especially Candida species. In Microbial Cell Surface Hydrophobicity, pp. 249-295. Edited by R. J. Doyle and M. Rosenberg. Washington, DC: American Society for Microbiology.

Hazen, K. C. \& Hazen, B. W. (1987). A polystyrene microsphere assay for detecting surface hydrophobicity variations within Candida albicans populations. J Microbiol Methods 6, 289-299.

Hazen, K. C., Lay, J. G., Hazen, B. W., Fu, R. C. \& Murthy, S. (1990). Partial biochemical characterization of cell surface hydrophobicity and hydrophilicity of Candida albicans. Infect Immun 58, 3469-3476.

Hearn, V. M. (1984). Surface antigens of intact Aspergillus fumigatus mycelium: their localization using radiolabelled protein $\mathrm{A}$ as marker. J Gen Microbiol 130, 907-917.

Hearn, V. M. (1992). Antigenicity of Aspergillus species. J Med Vet Mycol 30, 11-25.

Hearn, V. M. \& Sietsma, J. H. (1994). Chemical and immunological analysis of the Aspergillus fumigatus cell wall. Microbiology 140, 789-795.

Hearn, V. M., Wilson, E. V., Latgé, J.-P. \& Mackenzie, D. W. R. (1990). Immunochemical studies of Aspergillus fumigatus mycelial antigens by polyacrylamide gel electrophoresis and Western blotting techniques. J Gen Microbiol 136, 1525-1535.

Hearn, V. M., Latgé, J. P. \& Prévost, M. C. (1991). Immunolocalization of Aspergillus fumigatus mycelial antigens. $J$ Med $V e t$ Mycol 29, 73-81.

Kwon-Chung, K. J. \& Bennett J. E. (1991). Aspergillosis. In Medical Mycology, pp. 201-247. Edited by K. J. Kwon-Chung \& J. E. Bennett. Philadelphia: Lea \& Febiger.

Laemmli, U. K. (1970). Cleavage of structural proteins during the assembly of the head of bacteriophage T4. Nature 227, 680-685.

Latgé, J.-P., Kobayashi, H., Debeaupuis, J. P., Diaquin, M., Sarfati, J., Wieruszeski, J. M., Parra, E., Bouchara, J. P. \& Fournet, B. (1994). Chemical and immunological characterization of the extracellular galactomannan of Aspergillus fumigatus. Infect Immun 62, 5424-5433.

López-Ribot, J. L., Casanova, M., Martínez, J. P. \& Sentandreu, R. (1991). Characterization of cell wall proteins of yeast and hydrophobic mycelial cells of Candida albicans. Infect Immun 59, 2324-2332.

López-Ribot, J. L., Gozalbo, D., Sepúlveda, P., Casanova, M. \& Martínez, J. P. (1995). Preliminary characterization of the material released to the culture medium by Candida albicans yeast and mycelial cells. Antonie Leeunenboek 68, 195-201.

Martínez, J. P., Casanova, M., Gil, M. L. \& Sentandreu, R. (1991). Analysis of the polypeptide composition of the cell walls of Neurospora crassa. Similarities with the proteinaceous material secreted by the slime variant. Mycol Res $95,315-319$.
Morrissey, J. H. (1981). Silver stain for protein in polyacrylamide gels : a modified procedure with enhanced uniform sensitivity. Anal Biochem 117, 307-310.

Parta, M., Chang, Y., Rulong, S., Pinto-DaSilva, P. \& KwongChung, K. J. (1994). HYP1, a hydrophobin gene from Aspergillus fumigatus, complements the rodletless phenotype in Aspergillus nidulans. Infect Immun 62, 4389-4395.

Peñalver, M. C., O'Connor, J. E., Martínez, J. P. \& Gil, M. L. (1996). Binding of human fibronectin to Aspergillus fumigatus conidia. Infect Immun 64, 1146-1153.

Ponton, J. \& Jones, J. M. (1986). Analysis of cell wall extracts of Candida albicans by sodium dodecyl sulfate-polyacrylamide gel electrophoresis and Western blot techniques. Infect Immun 53, 565-572.

Reijula, K. E., Kurup, V. P., Kumar, A. \& Fink, J. N. (1992). Monoclonal antibodies bind identically to both spores and hyphae of Aspergillus fumigatus. Clin Exp Allergy 22, 547-553.

Rosenberg, M., Gutnick, D. \& Rosenberg, E. (1980). Adherence of bacteria to hydrocarbons: a simple method for measuring cellsurface hydrophobicity. FEMS Microbiol Lett 9, 29-33.

Rotrosen, D., Calderone, R. A. \& Edwards, J. E. (1986). Adherence of Candida species to host tissues and plastic surfaces. Rev Infect Dis 8, 73-85.

Silva, T. M. J., Glee, P. M. \& Hazen, K. C. (1995). Influence of cell surface hydrophobicity on attachment of Candida albicans to extracellular matrix proteins. J Med Vet Mycol 33, 117-122.

Ste-Marie, L., Senechal, S., Boushira, M., Garzon, S., Strykowski, H., Pedneault, L. \& de Repentigny, L. (1990). Production and characterization of monoclonal antibodies to cell wall antigens of Aspergillus fumigatus. Infect Immun 58, 2105-2114.

Sturtevant, J. E. \& Latgé, J.-P. (1992). Interactions between conidia of Aspergillus fumigatus and human complement C3. Infect Immun 60, 1913-1918.

Stynen, D., Sarfati, J., Goris, A., Prévost, M. C., Lesourd, M., Kamphuis, H., Darras, V. \& Latgé, J.-P. (1992). Rat monoclonal antibodies against Aspergillus galactomannan. Infect Immun 60, $2237-2245$.

Thau, N., Monod, M., Crestani, B., Rolland, C., Tronchin, G., Latgé, J.-P. \& Paris, S. (1994). rodletless mutants of Aspergillus fumigatus. Infect Immun 62, 4380-4388.

Tronchin, G., Bouchara, J. P., Larcher, G., Lissitsky, J. C. \& Chabasse, D. (1993). Interaction between Aspergillus fumigatus and basement membrane laminin: binding and substrate degradation. Biol Cell 77, 201-208.

Wilson, E. V. \& Hearn, V. M. (1982). A comparison of surface and cytoplasmic antigens of Aspergillus fumigatus in an enzyme-linked immunosorbent assay (ELISA). Mykosen 25, 653-661.

Received 19 December 1995; revised 31 January 1996; accepted 8 February 1996. 